\title{
Developing CIGS solar cells on glass-ceramic substrates
}

\author{
D. Fraga*, E. Barrachina, I. Calvet, T. Stoyanova, J.B. Carda \\ Department of Inorganic and Organic Chemistry, Universitat Jaume I, Castellón, 12071 \\ (Spain)
}

\begin{abstract}
$\mathrm{Cu}$ (In, Ga)Se $\mathrm{Se}_{2}$ (CIGS) is a p-type semiconductor material and an attractive absorber for thin films solar cells due to its unique optical and electrical properties. The low cost of this technology is based on its application on ecological substrates (glass, ceramic or glass-ceramic materials), effective uses of raw materials and lower thickness of the film (range from 1.5 to $3 \mu \mathrm{m}$ ). In this work, a new glass-ceramic substrate has been developed using industrial wastes materials (recycled glass, bottom ash and fly ash from a thermal power plant) used as support in thin film solar cell technology. The CIGS absorber has been synthesized by an easy and low-cost way of preparation using the coprecipitation method. The solar cell device has been completed and fully characterized. The obtained films were characterized by X-Ray diffraction (XRD), scanning electron microscope (SEM) and electrical characterization. The short circuit current (Jsc), open circuit voltage (Voc), fill factor (FF), and total area power conversion efficiency $(\eta)$ of the device are $8,11 \mathrm{~mA} / \mathrm{cm}^{2}, 168,2 \mathrm{mV}, 27,6 \%$ and $0,4 \%$ respectively.
\end{abstract}

Keywords: Glass-ceramic, Ceramics, Semiconductor, Solar energy materials, Thin films 


\section{Introduction}

A thin film technology is an attractive option for substitution of the classical silicon crystalline solar cells. This technology permits easy installation of the photovoltaic modules, bringing not only financial benefits from solar power generation, but also increasing the social values by making the buildings go green by simple retrofitting [1, 2]. Recently, encouraging results have been obtained for CIGS based solar cells applied on soda-lime glasses [3], ceramic substrates [4] and light-weight polymers [5]. Conception of new architectural elements with added photovoltaic (PV) functionalities creates a strong interest in the analysis of the extension of these technologies to these new families of substrates. In this work, an extension of the CIGS based technologies to glass-ceramic substrates is proposed, demonstrating its potential for the manufacture of low cost, and eco-friendly devices suitable for development of light solar modules that can be transferred from laboratory to pilot scale and then finally to production.

Currently, the use of ecological products become of a vast importance in the ceramic industry in order to optimize the consumption of natural resources and to the growing attention to the environmental safeguard because the residues cause an big environmental impact and increase the industrial running costs. The Circular economy offers an opportunity to reinvent our economy, making it more sustainable and competitive. This will bring benefits for European businesses, industries, and citizens alike.

The vitrification process is able to increasing the chemical uniformity of heterogeneous mixtures containing even toxic and hazardous heavy metals, achieving sufficient compositional stability of the system and thus modulating the final properties to ensure the reuse of the residue as raw material. In this way, the vitrification process can be a method to isolate, inertify and even recycle mineral residues $[6,7]$. The incorporation of recycled material in the glass ceramic process allows its conservation and reduces the use of natural resources. In this paper, the development of new CIGS solar cell on environmentally friendly glass-ceramic substrates is reported. The wastes come from the recycling glass and the ash waste from thermic central. 


\section{Materials and methods}

\subsection{Glass ceramic}

The glass-ceramic substrate with $3 \mathrm{~mm}$ thickness was prepared. The composition was prepared using soda-lime glass waste $(50 \% \mathrm{wt})$, bottom ash $(25 \% \mathrm{wt})$, fly ash $(15 \% \mathrm{wt})$ and $\mathrm{CaCO}_{3}(10 \% \mathrm{wt})$. The powders were melted at $1500^{\circ} \mathrm{C}$ for $1 \mathrm{~h}$. The melt was quenched into water obtaining shape glass. Grinding and sintering experiments were performed on rectangular compacts $\left(2 \times 5 \mathrm{~cm}^{2}\right)$ obtained by uniaxial pressing of the fine powder. The compacts were treated at $950^{\circ} \mathrm{C}\left(20^{\circ} \mathrm{C} / \mathrm{min}\right)$ during 30 minutes.

\subsection{CIGS synthesis and deposition}

$\mathrm{CuIn} \mathrm{I}_{0.7} \mathrm{Ga}_{0.3} \mathrm{Se}_{2}$ solid solution was synthesized using co-precipitation route and further deposited by doctor blade technique according the procedure described in the literature [8]. The obtained layer was pre-heated on a hot plate at $400^{\circ} \mathrm{C}$ for 2 min to partially remove the solvent and to encourage further precursor decomposition. Finally, the CIGS films were selenised using elemental Se under an Ar atmosphere in a tubular furnace. The applied thermal cycle corresponds to heating velocity rate of $20{ }^{\circ} \mathrm{C} / \mathrm{min}$ up to maximum temperature of $525^{\circ} \mathrm{C}$. In order to remove secondary phases, the absorbers were chemically etching with diluted $\mathrm{KCN}$. Immediately, the solar cells were completed depositing CdS (60 $\mathrm{nm}$ ) by chemical bath deposition (CBD) above the absorber layers. The i-ZnO layer with $50 \mathrm{~nm}$ thickness was deposited by the DC-pulsed sputtering deposition using $\mathrm{ZnO}$ target and $\mathrm{Ar} / \mathrm{O}_{2}$ mixture as process gas. The cells were completed with the deposition of a conductive indium tin oxide (ITO). For the optoelectronic characterization $3 \times 3 \mathrm{~mm}^{2}$ cells were scribed using a micro diamond scriber MR200 OEG.

\subsection{Characterization techniques}

Glass-ceramic composition has been studied by X-Ray Fluorescence (XRF), using a sequential spectrometer X-ray scattering wavelengths S4 Pioneer by Bruker with a Rh $\mathrm{X}$-ray tube of $4 \mathrm{~kW}$. The flexural strength of the glass-ceramic composition was measured using Crometro R5 equipment according to the standards.

The crystal structure of glass-ceramic and the CIGS films were monitored by X-ray diffraction (XRD) using a D4 Endeavor, Bruker-AXS equipped with a $\mathrm{Cu} \mathrm{K} \alpha$ radiation source. Data was collected by step-scanning from $10^{\circ}$ to $80^{\circ}$ with step size of $0.05^{\circ} 2 \theta$ and $1 \mathrm{~s}$ counting time per step. Scanning Electron Microscopy (SEM) model JEOL $7001 \mathrm{~F}$ attached with an energy dispersive X-ray analysis (EDX) was employed to study the morphology and elemental composition of the CIGS films. The layer thickness was valued from cross-section micrographs. The solar cells were optoelectronically characterized through I-V curves. A Sun 3000 class AAA solar simulator from Abet Technology (uniform illumination area of $15 \times 15 \mathrm{~cm}^{2}$ ) was used. Measurements were carried out after the calibration of the system with a reference Si solar cell under AM 1.5 illumination and fixing the temperature of the samples to $298 \mathrm{~K}$. All solar cell parameters and efficiencies presented refer to the active area $\left(0.087 \mathrm{~cm}^{2}\right)$ of the devices. 



\section{Results and discussion}

Chemical analyses of industrial and the glass-ceramic composition developed were determined by X-ray fluorescence (Table 1). Results of the chemical analysis showed a sodium-calcium nature of the waste glass. Fly ash and bottom ash exhibited high quantity of $\mathrm{Fe}_{2} \mathrm{O}_{3}$. On the other hand, glass waste is composed mainly by $\mathrm{SiO}_{2}, \mathrm{Na}_{2} \mathrm{O}$ and $\mathrm{CaO}$. The glass-ceramic sample revealed a $\mathrm{SiO}_{2}-\mathrm{Al}_{2} \mathrm{O}_{3}$ composition with high quantity of $\mathrm{Fe}_{2} \mathrm{O}_{3}$ and $\mathrm{CaO}$.

Table 1. XRF analysis of the wastes and the glass-ceramic prepared.

\begin{tabular}{|c|c|c|c|c|c|c|c|c|c|c|c|}
\hline $\mathbf{W t} \%$ & $\mathbf{N a}_{2} \mathbf{O}$ & $\mathbf{M g O}$ & $\mathbf{A l}_{\mathbf{2}} \mathbf{O}_{\mathbf{3}}$ & $\mathbf{S i O}_{2}$ & $\mathbf{P}_{\mathbf{2}} \mathbf{O}_{\mathbf{5}}$ & $\mathbf{K}_{\mathbf{2}} \mathbf{O}$ & $\mathbf{C a O}$ & $\mathbf{T i O}_{\mathbf{2}}$ & $\mathbf{S O}_{\mathbf{3}}$ & $\mathbf{F e}_{\mathbf{2}} \mathbf{O}_{\mathbf{3}}$ & $\mathbf{L O I}$ \\
\hline Glass waste & 12,59 & 3,75 & 0,85 & 73,16 & 0,01 & 0,30 & 8,94 & 0,05 & 0,20 & 0,10 & 0,10 \\
\hline Fly ash & 0,20 & 1,23 & 26,63 & 44,44 & 0,41 & 1,23 & 5,53 & 0,92 & 0,72 & 18,43 & 0,15 \\
\hline Bottom ash & 0,00 & 1,13 & 23,85 & 43,19 & 0,31 & 1,13 & 5,22 & 0,72 & 0,20 & 23,85 & 0,20 \\
\hline Glass-ceramic & 6,83 & 2,10 & 17,05 & 52,75 & - & 0,78 & 12,34 & 0,36 & - & 7,69 & 0,05 \\
\hline
\end{tabular}

*LOI: lost on ignition

Glass-ceramic with $3 \mathrm{~mm}$ thickness used as a device substrate is shown in Figure 1a, before thin film components deposition. The bending resistance obtained was 950 $\mathrm{kg} / \mathrm{cm}^{2}$. This value is higher than the mechanical strength of conventional ceramic paste. Photovoltaic components are integrated onto glass-ceramic to complete the solar cell device. Image of the final device is shown in Figure $1 \mathrm{~b}$.

(a)

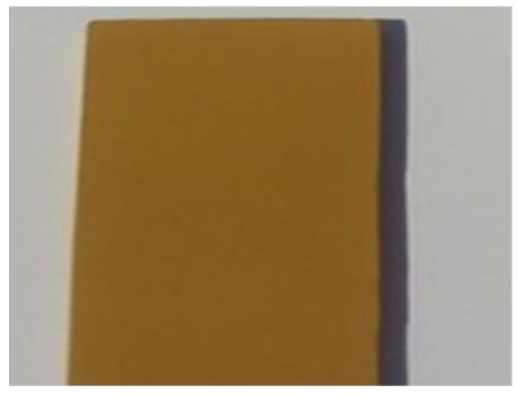

(b)

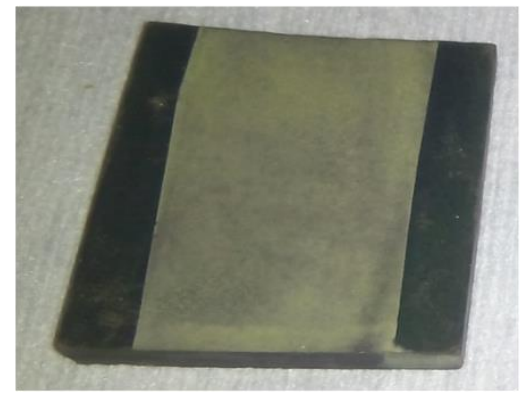

Figure 1. (a) Digital image of the glass-ceramic substrate and (b) Digital image of the solar cell device assembled.

The X-ray diffraction spectra of glass-ceramic treated at $950^{\circ} \mathrm{C}$ are exposed in Figure $2 \mathrm{a}$. The main diffraction peaks of sample could be assigned to sodium anorthite (JCPDS 86-1650) and hedenbergite phases (JCPDS 70-1876) demonstrating the viability of the vitrification process. Figure $2 \mathrm{~b}$ shows the X-ray diffraction spectra of CIGS films treated at $525^{\circ} \mathrm{C}$. The diffraction peaks labelled with $h k l$ could be assigned to $\mathrm{CuIn}_{0,7} \mathrm{Ga}_{0,3} \mathrm{Se}_{2}$ (CIGS) crystalline phase (JCPDS 35-1102). The highest Mo back contact reflection is observed at $40.6^{\circ}$ and $73.7^{\circ} 2$ theta (JCPDS 42-1120). Extra peaks were also detected at $2 \theta: 31.82^{\circ}$ and $53.07^{\circ}$ that could be assigned to $\mathrm{MoSe}_{2}$ phase (JCPDS 20-0757). 

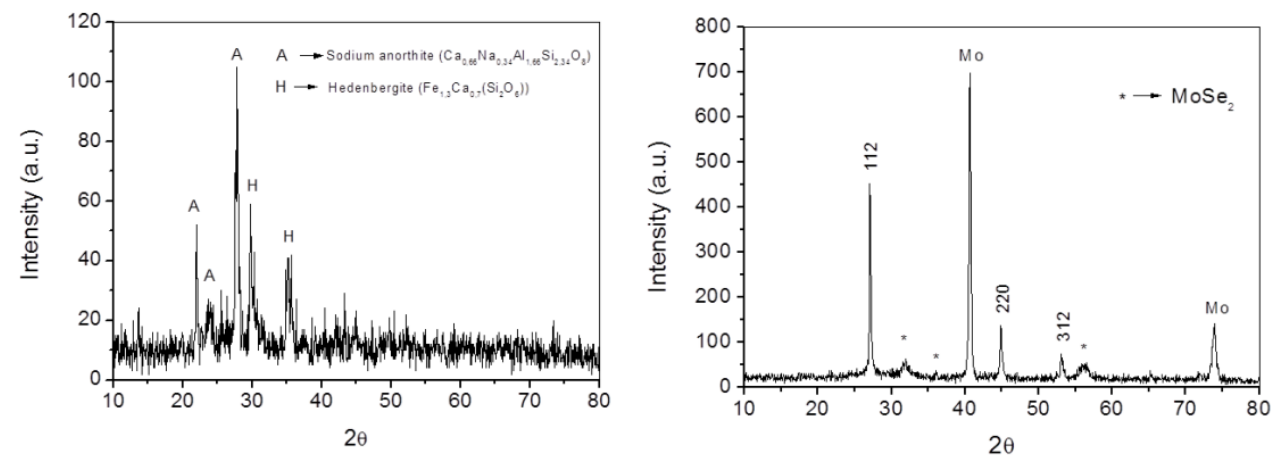

Figure 2. (a) XRD analysis of glass-ceramic composition treated at $950^{\circ} \mathrm{C}$ during 30 and (b) XRD of CIGS film treated at $525^{\circ} \mathrm{C}$.

The solar cells is composed by glass-ceramic (substrate) followed by Mo coating ( $800 \mathrm{~nm}$ ) as a conductive back contact for the device. The absorber CIGS layer obtained has $\sim 1,5 \mu \mathrm{m}$ thickness. The adhered absorber film has been also tested by conventional laboratory taping test consisting of detaching the tapes from the surface showing very good adhesion on the molybdenum. Finally, CdS buffer $(-20 \mathrm{~nm})$, zinc oxide $(-50 \mathrm{~nm})$ and ITO window layers $(-400 \mathrm{~nm})$ were deposited to complete the solar cell device. The CIGS devices were optoelectronically characterized through current density-voltage (JV) curves under AM1.5 global spectrum. The photovoltaic behaviour has an opencircuit voltage $\left(\mathrm{V}_{\mathrm{oc}}\right)=168.2 \mathrm{mV}$, short-circuit current density $\left(\mathrm{J}_{\mathrm{sc}}\right)=8.11 \mathrm{~mA} / \mathrm{cm}^{2}$, fill factor $(\mathrm{FF})=27.6 \%$, efficiency $(\eta)=0.4 \%$, and device area $=0.087 \mathrm{~cm}^{2}$. It can be observed that it is possible to prepare a photovoltaic device based on film layer technology, using glass-ceramic containing industrial waste as mainly part of raw materials for the substrate formulation.

\section{Conclusions}

Glass ceramic as alternative substrates for CIGS thin film solar cells have been developed. The CIGS absorber has been synthesized with a simple and easy method using water as solvent. Finally, the solar cell device has been completed and characterized.

The designed glass ceramic, including industrial wastes in its formulation, achieved better results in terms of lower porosity and water absorption, mechanical resistance, lower body thickness and crystalline phases of sodium anorthite and hedenbergite. These characteristics render it as a proper substrate for photovoltaic applications developing device with $0.4 \%$ of efficiency.

In summary, a glass-ceramic using industrial wastes has been developed, demonstrating to be suitable as a substrate for CIGS thin film solar cell. The device allows both, functionality and energy saving during the manufacturing process. 


\section{Acknowledgments}

The authors would like to acknowledge the financial support of the Spanish Ministry of Economy and Competitiveness under the program RETOS-COLABORACION (RTC2014-2294-3). We also appreciate the characterization assistance of Central Service of Scientific Instrumentation (SCIC) at the University Jaume I. The authors thank the group of A. Perez (Catalonia Institute for Energy Research-IREC) for the help in the solar cell assemble. 


\section{References}

[1] B. Petter Jelle, C. Breivik, H. Drolsum Røkenes, Sol. Energ. Mat. Sol. C., 100 (2012) 69-96.

[2] B.P. Jelle, C. Breivik, Energy Procedia 20 (2012) 78-87.

[3] P. Jackson, D. Hariskos, R. Wuerz, O. Kiowski, A. Bauer, T.M. Friedlmeier, M. Powalla, Phys. Status Solidi R., 9(1) (2015) 28-31.

[4] D. Fraga, T. Stoyanova Lyubenova, R. Martí, I. Calvet, E. Barrachina, J.B. Carda, Sol. Energy, 147 (2017) 1-7.

[5] K.E. Martin A. Green, Yoshihiro Hishikawa, Wilhelm Warta and Ewan D. Dunlop, Prog. Photovoltaics, 21 (2013) 827-837.

[6] B. Cicek, A. Tucci, E. Bernardo, J. Will, A.R. Boccaccini, Ceram. Int., 40(4) (2014) 6045-6051.

[7] Z. Lu, J. Lu, X. Li, G. Shao, Ceram. Int., 42(2) (2016) 3452-3459.

[8] R. Martí, L. Oliveira, T.S. Lyubenova, T. Todorov, E. Chassaing, D. Lincot, J.B. Carda, J. Alloy. Comp., 650 (2015) 907-911. 